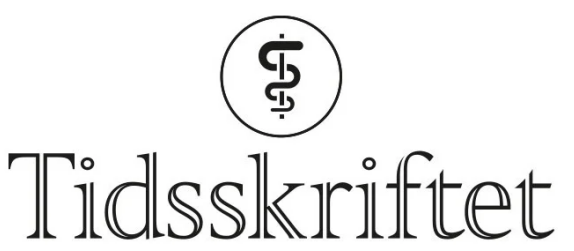

DEN NORSKE LEGEFORENING

\title{
Rastløse bein - en studie fra allmennpraksis
}

ORIGINALARTIKKEL

\section{BJ $\varnothing R N$ BJORVATN}

bjorn.bjorvatn@uib.no

Institutt for global helse og samfunnsmedisin

Universitetet i Bergen

og

Nasjonal kompetansetjeneste for søvnsykdommer

Haukeland universitetssjukehus

Han har bidratt med idé, planlegging og utforming, revisjon og endelig godkjenning av manuskriptet.

Bjørn Bjorvatn er spesialist i allmennmedisin, søvnspesialist ved Bergen søvnsenter, professor og leder (Nasjonal kompetansetjeneste for søvnsykdommer).

Forfatteren har fylt ut ICMJE-skjemaet og oppgir ingen interessekonflikter.

\section{KNUT-ARNE WENSAAS}

Allmennmedisinsk forskningsenhet NORCE Norwegian Research Centre Bergen

Han har bidratt med idé, planlegging og utforming, revisjon og endelig godkjenning av manuskriptet.

Knut-Arne Wensaas er spesialist i allmennmedisin og seniorforsker.

Forfatteren har fylt ut ICMJE-skjemaet og oppgir ingen interessekonflikter.

\section{KNUT ERIK EMBERLAND}

Institutt for global helse og samfunnsmedisin Universitetet i Bergen

og

Allmennmedisinsk forskningsenhet NORCE Norwegian Research Centre Bergen

Han har bidratt med idé, planlegging og utforming, revisjon og endelig godkjenning av manuskriptet.

Knut Erik Emberland er lege i spesialisering i allmennmedisin, ph.d.-kandidat og faglig tilknyttet Norwegian Research Centre.

Forfatteren har fylt ut ICMJE-skjemaet og oppgir ingen interessekonflikter.

\section{LARS THORE FADNES}

Institutt for global helse og samfunnsmedisin Universitetet i Bergen

og

Bergen Addiction Research Avdeling for rusmedisin 
Haukeland universitetssjukehus

Han har bidratt med idé, planlegging og utforming, revisjon og endelig godkjenning av manuskriptet.

Lars Thore Fadnes er spesialist i allmennmedisin, professor og forskningsgruppeleder. Forfatteren har fylt ut ICMJE-skjemaet og oppgir ingen interessekonflikter.

\section{SVERRE LITLESKARE}

Allmennmedisinsk forskningsenhet NORCE Norwegian Research Centre Bergen

Han har bidratt med idé, planlegging og utforming, revisjon og endelig godkjenning av manuskriptet.

Sverre Litleskare er lege i spesialisering i allmennmedisin og seniorforsker.

Forfatteren har fylt ut ICMJE-skjemaet og oppgir ingen interessekonflikter.

\section{ESPERANZA DIAZ}

Institutt for global helse og samfunnsmedisin

Universitetet i Bergen

og

Enhet for migrasjonshelse

Folkehelseinstituttet

Hun har bidratt med idé, planlegging og utforming, revisjon og endelig godkjenning av manuskriptet.

Esperanza Diaz er spesialist i allmennmedisin, professor, leder for Pandemisenteret ved Universitetet i Bergen og seniorforsker.

Forfatteren har fylt ut ICMJE-skjemaet og oppgir ingen interessekonflikter.

\section{SABINE RUTHS}

Institutt for global helse og samfunnsmedisin

Universitetet i Bergen

og

Allmennmedisinsk forskningsenhet

NORCE Norwegian Research Centre

Bergen

Hun har bidratt med idé, planlegging og utforming, revisjon og endelig godkjenning av manuskriptet.

Sabine Ruths er spesialist i allmennmedisin, professor og seniorforsker.

Forfatteren har fylt ut ICMJE-skjemaet og oppgir ingen interessekonflikter.

\section{GURI RøRTVEIT}

Institutt for global helse og samfunnsmedisin

Universitetet i Bergen

og

Allmennmedisinsk forskningsenhet

NORCE Norwegian Research Centre

Bergen

Hun har bidratt med idé, planlegging og utforming, revisjon og endelig godkjenning av manuskriptet.

Guri Rørtveit er spesialist i allmennmedisin, professor og forsker ved Norwegian Research Centre. Forfatteren har fylt ut ICMJE-skjemaet og oppgir ingen interessekonflikter.

\section{SIRI WAAGE}

Institutt for global helse og samfunnsmedisin

Universitetet i Bergen

og

Nasjonal kompetansetjeneste for søvnsykdommer

Haukeland universitetssjukehus

Hun har bidratt med idé, planlegging og utforming, revisjon og endelig godkjenning av manuskriptet.

Siri Waage er forsker og senterkoordinator (Nasjonal kompetansetjeneste for søvnsykdommer). Forfatteren har fylt ut ICMJE-skjemaet og oppgir ingen interessekonflikter. 
Forekomsten av rastløse bein er rundt 5-10 \% blant voksne i den generelle befolkningen. Få studier er gjort om forekomsten blant pasienter som oppsøker fastlege. Det er også få studier om sammenheng med andre vanlige plager som irritabel tarm, kronisk utmattelse eller kronisk muskel- og ryggsmerte.

\section{MATERIALE OG METODE}

Studien ble gjennomført som en spørreskjemaundersøkelse ved legekontorer på Sør- og Vestlandet høsten 2017 og våren 2018, der pasienter som ventet på time hos fastlegen fortløpende ble invitert til å delta. 2634 personer deltok (62,2 \% kvinner, gjennomsnittsalder 49,6 år). Svarprosenten var 86,8. Rastløse bein ble definert basert på internasjonale kriterier. Assosiasjoner mellom rastløse bein og irritabel tarm, kronisk utmattelse og kronisk muskel- og ryggsmerte ble analysert med khikvadrattester og logistisk regresjon.

\section{RESULTATER OG FORTOLKNING}

Andelen pasienter med rastløse bein var 14,3\%. Blant pasientene med rastløse bein rapporterte $44,8 \%$ at symptomene var moderate til veldig plagsomme, og $85,8 \%$ at de ikke brukte medikamenter for dette. Andelen pasienter med rastløse bein var signifikant høyere blant pasienter med irritabel tarm (21,8\% versus $13,6 \%, \mathrm{p}=0,009)$, kronisk utmattelse $(18,2 \%$ versus $13,1 \%, \mathrm{p}=$ o,o03) og kronisk muskel- og ryggsmerte (23,2\% versus $12,2 \%, \mathrm{p}<$ o,0005). Fastleger bør være oppmerksomme på at mange pasienter har rastløse bein og at tilstanden er assosiert med andre vanlige plager.

\section{HOVEDFUNN}

Forekomsten av rastløse bein var 14,3\% blant pasienter som oppsøker fastlegen.

Rundt halvparten av dem oppga mye og hyppige plager, men et fåtall benyttet medikamentell behandling.

Rastløse bein var hyppigere blant pasienter med andre plager som irritabel tarm (justert oddsratio (OR) 1,73), kronisk utmattelse (OR 1,48) og kronisk muskel- og ryggsmerte (OR 2,06), sammenliknet med pasienter uten disse tilstandene.

Rastløse bein kjennetegnes av kriblende og ubehagelige fornemmelser i beina ledsaget av trang til bevegelse $(\underline{1}, \underline{2})$. Denne bevegelsestrangen oppstår når man er i ro og forsvinner helt eller delvis ved bevegelse. Trangen har også en tydelig døgnvariasjon, hvor symptomer er til stede kveld og natt, og ikke tidlig på dagen (므). På grunn av relasjonen til kveld/natt regnes rastløse bein som en søvnrelatert bevegelseslidelse (2, 3). Samtidig er tilstanden også klassifisert som en nevrologisk lidelse, som ofte starter i voksen alder og varer livet ut $(\underline{1}, \underline{2})$.

Undersøkelser fra flere vestlige land angir forekomsten av diagnosen rastløse bein (også kalt restless legs syndrome) til å være 5-10 \% (1,3,4.). I en norsk befolkningsundersøkelse fra 2005 tilfredsstilte $14,3 \%$ av voksne personer kriteriene for rastløse bein, og omtrent halvparten beskrev plagene som moderate eller alvorlige (5). Det er flest kvinner som rapporterer plager, og forekomsten øker med alderen (3). Til tross for at tilstanden er vanlig, forblir den ofte udiagnostisert og ubehandlet $(3, \underline{4}, \underline{6})$.

Det er $ø \mathrm{kt}$ forekomst av rastløse bein hos pasienter med nyresvikt, jernmangel, graviditet og hos pasienter som bruker visse medikamenter $(3,7, \underline{8})$. Årsaksmekanismene til rastløse bein er ukjente, men nedsatt funksjon i det dopaminerge systemet er påvist (1). Forstyrrelser i jernomsetningen ser også ut til å spille en rolle $(\underline{1}, \underline{8})$. Genetiske faktorer har betydning, og 40-50 \% av pasienter med denne diagnosen kjenner andre i familien med liknende plager $(3, \underline{8})$. 
Behandlingen av rastløse bein er avhengig av graden av symptomer. Ved lette eller sjeldne plager tilrådes ikke-medikamentell behandling. Symptomene lindres av bevegelse, og massasje av muskulaturen i beina kan også hjelpe. God søvnhygiene er viktig (3.9.).

Døgnrytmen bør være så stabil som mulig. Koffeinholdige drikker bør unngås på kveldstid. Alkohol og nikotin kan utløse eller forverre rastløse bein hos disponerte pasienter. Lidelsen kan også oppstå som bivirkning av enkelte medikamenter (som f.eks. antidepressiver og antipsykotika), og endring av preparat eller doseringstidspunkt kan være tjenlig.

Ved hyppige og mer alvorlige plager anbefales vanligvis medikamentell behandling. Jerntilskudd kan ha god effekt (9.), og det anbefales å gi jerntilskudd ved ferritinnivåer under $50 \mu \mathrm{g} / \mathrm{L}(\underline{10})$. Førstehåndspreparater ved rastløse bein har i mange år vært medikamenter som stimulerer dopaminreseptorer i hjernen (dopaminagonister) (3,9, 11). Effekten er ofte svært god, og ved manglende effekt bør diagnosen revurderes. Det er ofte fa initiale bivirkninger, men et problem med dopaminagonister er avtakende effekt og risiko for symptomforverring (augmentasjon) over tid. Det finnes alternativer til dopaminagonister. Mest aktuelle alternativer er alfa-2-delta-ligander (gabapentin og pregabalin), og disse preparatene er også foreslått som førstehåndspreparater ved rastløse bein (1).

Det er lite kunnskap om forekomsten av rastløse bein i norsk allmennpraksis. For andre søvnlidelser, som for eksempel insomni, viste en norsk studie at forekomsten er mer enn dobbelt så høy blant pasienter på fastlegekontoret sammenliknet med befolkningsundersøkelser, fordi insomni er hyppigere blant personer med andre

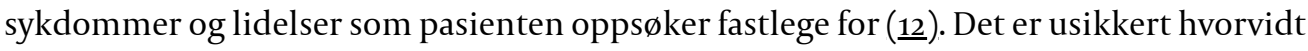
dette også gjelder for rastløse bein. Det er i tillegg uklart om denne lidelsen er assosiert med andre vanlige plager som sees på fastlegekontoret.

Målet med denne studien var derfor å undersøke forekomsten av rastløse bein blant pasienter som oppsøker fastlege. I tillegg ønsket vi å studere alvorlighetsgraden og om pasientene benyttet medikamenter for plagene. Vi ønsket videre å studere om forekomsten av rastløse bein var assosiert med andre vanlige tilstander som pasienter oppsøker fastlegen for, slik som irritabel tarm, kronisk utmattelse og kronisk muskel- og ryggsmerte.

\section{Materiale og metode}

Datainnsamlingen ble gjennomført på fastlegekontorer på Vestlandet og Sørlandet som tok imot 6. års medisinstudenter i praksisperiode fra Universitetet i Bergen høsten 2017 og våren 2018.

I den aktuelle studien ble hver medisinstudent instruert i å invitere 20 fortløpende pasienter på venterommet til å fylle ut et spørreskjema på én side. Ut over at pasientene måtte være over 18 år, var det ingen inklusjons- eller eksklusjonskriterier. Pasientene fikk ikke informasjon på forhånd om hvilke spørsmål skjemaet inneholdt. Spørreskjemaet (se appendiks på tidsskriftet.no) ble delt ut av enten student eller legesekretær ved fastlegekontoret. Utfylte skjemaer ble levert tilbake til studenten/legesekretæren i lukket konvolutt. Ingen direkte personidentifiserende data ble samlet inn.

Totalt leverte 150 studenter ut 2979 spørreskjemaer. Hver student leverte i gjennomsnitt ut 19,9 skjemaer (spredning fra 11 til 28). 2585 besvarte spørreskjemaer ble levert inn, noe som gir en svarprosent på 86,8. I tillegg kom det inn 115 spørreskjemaer fra syv studenter som ikke oppga hvor mange skjemaer de hadde utlevert. Av de totalt 2700 spørreskjemaene med besvarelser ble 66 ekskludert fordi pasientene var under 18 år. Datamaterialet i studien består derfor av totalt 2634 svar på spørreskjemaet.

Spørreskjemaet inneholdt spørsmål om alder, kjønn, fødeland og utdanning. Hovedutfall i studien var rastløse bein, hvor vi definerte tilstedeværelse basert på internasjonale kriterier (2) (ramme 1). 
Ramme 1 Spørsmålene som ble benyttet til å definere rastløse bein, basert på internasjonale retningslinjer (2). Hvis pasienten svarer ja på alle fire spørsmål, er kriteriene for diagnosen oppfylt.

1. Har du en trang til å bevege beina, vanligvis i forbindelse med ubehag eller ubestemmelig kribling eller mauring i beina?

2. Hvis ja, begynner eller øker denne trangen når du er i ro, som for eksempel når du ligger eller sitter?

3. Er trangen til bevegelse eller de ubehagelige kriblingene delvis eller helt borte når du er i bevegelse, som for eksempel når du går eller når du strekker deg?

4. Er trangen til bevegelse eller de ubehagelige kriblingene verre sent på dagen eller om natten enn resten av dagen?

Pasienter som svarte ja på alle de fire spørsmålene, ble klassifisert til å ha rastløse bein i tråd med retningslinjene (므). Pasienter med rastløse bein ble bedt om å beskrive hvor plagsom bevegelsestrangen var på en fireleddet skala, mens hyppigheten ble kartlagt ved at pasienten anga dette på en femleddet skala (appendiks). Skjemaet inkluderte spørsmål om medikamentbruk mot rastløse bein.

Pasientene besvarte også spørsmål om følgende plager: kronisk utmattelse, kronisk muskel- og ryggsmerte og irritabel tarm, med femleddede Likert-skalaer (appendiks). De to spørsmålene om kronisk utmattelse ble hentet fra Fatigue Questionnaire (13), og vi valgte disse spørsmålene fordi de korrelerte best med «kronisk utmattelse» i kontrollgruppen i en tidligere studie (14.). Dersom pasienten besvarte begge spørsmål med «over 6 måneder» definerte vi det som kronisk utmattelse. Spørsmålene om kronisk muskel- og ryggsmerte er ikke validert i tidligere studier, men ble valgt ut fra klinisk skjønn for å fange opp utbredte smerter. Vi stilte samme krav til varighet her som for kronisk utmattelse for å klassifisere plagene som kroniske. Spørsmålene om irritabel tarm ble utformet slik at de kunne identifisere pasienter med irritabel tarm-syndrom i henhold til Roma IV-kriteriene fra 2016 (15).

Prosjektet ble godkjent av Regional komité for medisinsk og helsefaglig forskningsetikk (REK), med referansenummer 2017/961.

Statistikkpakken SPSS (versjon 27) ble benyttet til statistiske analyser. Assosiasjoner mellom rastløse bein og ulike pasientvariabler ble analysert med khikvadrattester og logistisk regresjon i univariate og alders- og kjønnsjusterte regresjonsanalyser. Signifikansnivået ble satt til o,05.

\section{Resultater}

Tabell 1 viser demografiske data og forekomsten av rastløse bein, irritabel tarm, kronisk utmattelse og kronisk muskel- og ryggsmerte. Utvalget bestod av 62,2 \% kvinner, og gjennomsnittsalderen var 49,6 år (spredning 18-95 år). I alt 89,6\% oppga Norge som fødeland, mens de vanligste andre fødelandene var Polen ( 26 personer), Sverige (18 personer), Tyskland (17 personer), Danmark (15 personer) og Island (11 personer).

\section{Tabell 1}

Demografiske data og forekomst av rastløse bein blant 2634 inkluderte pasienter som oppsøkte fastlegekontorer på Sørlandet og Vestlandet høsten 2017/våren 2018. 


\begin{tabular}{|c|c|c|}
\hline Variabel & Antall (\%) & Valid prosent $^{1}$ \\
\hline \multicolumn{3}{|l|}{ Kjønn } \\
\hline Kvinne & $1634(62,0)$ & 62,2 \\
\hline Mann & $994(37,7)$ & 37,8 \\
\hline Mangler data & $6(0,2)$ & \\
\hline \multicolumn{3}{|l|}{ Alder (år) } \\
\hline $18-29$ & $456(17,3)$ & 17,4 \\
\hline $30-39$ & $441(16,7)$ & 16,9 \\
\hline $40-49$ & $412(15,6)$ & 15,8 \\
\hline $50-59$ & $419(15,9)$ & 16,0 \\
\hline $60-69$ & $448(17,0)$ & 17,1 \\
\hline $70-79$ & $333(12,6)$ & 12,7 \\
\hline $80+$ & $106(4,0)$ & 4,1 \\
\hline Mangler data & $49(0,7)$ & \\
\hline \multicolumn{3}{|l|}{ Fødeland } \\
\hline Norge & $2359(89,6)$ & 90,1 \\
\hline Andre land & $259(9,8)$ & 9,9 \\
\hline Mangler data & $16(0,6)$ & \\
\hline \multicolumn{3}{|l|}{ Utdanning } \\
\hline Grunnskole & $267(10,1)$ & 10,3 \\
\hline Videregående & $1257(47,7)$ & 48,7 \\
\hline Universitet/ høyskole & $1056(40,1)$ & 40,9 \\
\hline Mangler data & $54(2,1)$ & \\
\hline \multicolumn{3}{|l|}{ Irritabel tarm } \\
\hline Nei & $2337(88,7)$ & 93,9 \\
\hline Ja & $152(5,8)$ & 6,1 \\
\hline Mangler data & $145(5,5)$ & \\
\hline \multicolumn{3}{|l|}{ Kronisk utmattelse } \\
\hline Nei & $1848(70,2)$ & 76,0 \\
\hline Ja & $583(22,1)$ & 24,0 \\
\hline Mangler data & $203(7,7)$ & \\
\hline \multicolumn{3}{|l|}{$\begin{array}{l}\text { Kroniske muskel-og } \\
\text { ryggsmerter }\end{array}$} \\
\hline Nei & $1938(73,6)$ & 80,0 \\
\hline Ja & $485(18,4)$ & 20,0 \\
\hline
\end{tabular}




\begin{tabular}{|lrr|}
\hline Variabel & Antall $(\%)$ & \multicolumn{2}{c|}{ Valid prosent } \\
\hline Mangler data & $211(8,0)$ & \\
\hline Rastløse bein & & 85,7 \\
\hline Nei & $2134(81,0)$ & 14,3 \\
\hline Ja & $355(13,5)$ & \\
\hline Mangler data & $145(5,5)$ & \\
\hline
\end{tabular}

${ }^{1}$ Her er manglende besvarelser fjernet i utregningen av prosent.

Blant deltakerne med valide svar oppfylte 14,3\% de diagnostiske kriteriene for rastløse bein, og $44,8 \%$ av disse rapporterte at symptomene var moderate eller veldig plagsomme (tabell 2). Blant dem som hadde rastløse bein oppga 20,2 \% at de hadde det «daglig» og 34,2\% at de hadde det «2-6 dager per uke». Et stort flertall $(85,8 \%)$ rapporterte at de ikke brukte medikamenter mot disse plagene, mens $4,8 \%$ og $8,5 \%$ brukte medikamenter henholdsvis «av og til» og «daglig».

\section{Tabell 2}

Alvorlighetsgrad av rastløse bein blant 355 av 2634 inkluderte pasienter som oppsøkte fastlegekontorer på Sørlandet og Vestlandet høsten 2017/våren 2018.

\begin{tabular}{|lrr|}
\hline Variabel & Antall (\%) & Valid prosent $^{1}$ \\
\hline Alvorlighetsgrad & $24(6,8)$ & 6,8 \\
\hline Ikke plagsomt & $171(48,5)$ & 48,4 \\
\hline Litt plagsomt & $103(29,0)$ & 29,2 \\
\hline Moderat plagsomt & $55(15,5)$ & 15,6 \\
\hline Veldig plagsomt & $2(0,6)$ & \\
\hline Mangler data & & 0,3 \\
\hline Hyppighet & $1(0,3)$ & 24,2 \\
\hline Aldri & $85(23,9)$ & 21,1 \\
\hline En sjelden gang & $74(20,8)$ & 34,2 \\
\hline 1 dag per uke & $120(33,8)$ & 20,2 \\
\hline $2-6$ dager per uke & $71(20,0)$ & 8,5 \\
\hline Daglig & $4(1,1)$ & 85,8 \\
\hline Mangler data & $3(0,8)$ & 4,8 \\
\hline Medikamentbruk & $301(84,8)$ & $(4,8)$ \\
\hline Nei & $30(8,5)$ & \\
\hline Ja, av og til & & \\
\hline Ja, daglig & & \\
\hline Vet ikke & & \\
\hline & & \\
\hline & & \\
\hline
\end{tabular}




\begin{tabular}{|ccc|}
\hline Variabel & Antall (\%) & Valid prosent \\
\hline Mangler data & $4(1,1)$ \\
\hline
\end{tabular}

${ }^{1}$ Her er manglende besvarelser fjernet i utregningen av prosent.

Det var signifikant flere kvinner enn menn med rastløse bein (tabell 3 ). Det var ingen tydelig sammenheng mellom alder og det å ha rastløse bein. Tilstanden var heller ikke signifikant assosiert med utdanningsnivå eller fødeland. Andelen med rastløse bein var signifikant høyere blant pasienter med irritabel tarm, kronisk utmattelse og kronisk muskel- og ryggsmerte enn blant pasienter uten disse tilstandene.

\section{Tabell 3}

Forekomst av diagnosen rastløse bein blant 2634 inkluderte pasienter som oppsøkte fastlegekontorer på Sørlandet og Vestlandet høsten 2017/våren 2018, etter kjønn, alder, utdanning, fødeland samt diagnosene irritabel tarm, kronisk utmattelse og kroniske muskel- og ryggsmerter.

\begin{tabular}{|c|c|c|c|}
\hline Variabel & Nei, n (\%) & $\mathrm{Ja}, \mathrm{n}(\%)$ & $P$-verdi \\
\hline Kjønn (n = 2 485) & & & 0,036 \\
\hline Mann & $826(87,7)$ & $116(12,3)$ & \\
\hline Kvinne & $1305(84,6)$ & $238(15,4)$ & \\
\hline Alder $(n=2472)$ & & & 0,141 \\
\hline 18-29 år & $392(89,1)$ & $48(10,9)$ & \\
\hline 30-39 år & $360(84,9)$ & $64(15,1)$ & \\
\hline 40-49 år & $343(86,2)$ & $55(13,8)$ & \\
\hline 50-59 år & $331(83,0)$ & $68(17,0)$ & \\
\hline 60-69 år & $353(83,6)$ & $69(16,4)$ & \\
\hline 70-79 år & $262(87,9)$ & $36(12,1)$ & \\
\hline $80+$ år & $79(86,8)$ & $12(13,2)$ & \\
\hline Utdanning ( $n=2447)$ & & & 0,514 \\
\hline Grunnskole & $203(83,2)$ & $41(16,8)$ & \\
\hline Videregående skole & $1016(86,0)$ & $165(14,0)$ & \\
\hline Universitet & $876(85,7)$ & $146(14,3)$ & \\
\hline Fødeland ( $n=2477)$ & & & 0,052 \\
\hline Norge & $1899(85,3)$ & $327(14,7)$ & \\
\hline Andre land & $226(90,0)$ & $25(10,0)$ & \\
\hline Irritabel tarm $(\mathrm{n}=2387)$ & & & 0,009 \\
\hline Nei & $1935(86,4)$ & $305(13,6)$ & \\
\hline Ja & $115(78,2)$ & $32(21,8)$ & \\
\hline
\end{tabular}




\begin{tabular}{|lrrr|}
\hline Variabel & Nei, n (\%) & Ja, n (\%) & \multicolumn{1}{c|}{$P$-verdi } \\
\hline Kronisk utmattelse $(\mathrm{n}=2328)$ & $1538(86,9)$ & 0,003 \\
\hline Nei & $457(81,8)$ & $102(18,2)$ & \\
\hline $\mathrm{Ja}$ & & & $<0,0005$ \\
\hline $\begin{array}{l}\text { Kroniske muskel- og ryggsmerter } \\
(\mathrm{n}=2 \text { 325) }\end{array}$ & $1629(87,8)$ & $227(12,2)$ & \\
\hline Nei & $360(76,8)$ & $109(23,2)$ & \\
\hline $\mathrm{Ja}$ & & & \\
\end{tabular}

Tabell 4 viser at pasienter med irritabel tarm hadde større sannsynlighet for rastløse bein (justert oddsratio (OR ) 1,73 (1,15-2,63)). Også pasienter med kronisk utmattelse hadde større sannsynlighet for å ha rastløse bein (justert OR 1,48 (1,14-1,91)). Sterkest assosiasjon var det mellom kronisk muskel- og ryggsmerte og rastløse bein (justert OR 2,06 (1,58-2,67)).

\section{Tabell 4}

Ujustert og justert logistisk regresjonsanalyse med diagnosen rastløse bein som avhengig variabel blant pasienter som oppsøkte fastlegekontorer på Sørlandet og Vestlandet høsten 2017/våren 2018. OR = oddsratio, $\mathrm{KI}=$ konfidensintervall.

\begin{tabular}{|c|c|c|}
\hline & $\begin{array}{l}\text { Ujustert analyse, } \\
\text { OR }(95 \% \mathrm{KI})^{1}\end{array}$ & $\begin{array}{l}\text { Justert analyse, } \\
\text { OR }(95 \% \mathrm{KI})^{2}\end{array}$ \\
\hline \multicolumn{3}{|l|}{ Kjønn (n = 2485$)$} \\
\hline Mann & \multirow{2}{*}{$\begin{array}{l}\text { Referanse } \\
1,30(1,02-1,65)\end{array}$} & \\
\hline Kvinne & & \\
\hline Alder $(n=2472)$ & $1,00(1,00-1,01)$ & \\
\hline \multicolumn{3}{|c|}{ Irritabel tarm $(n=2369-2387)$} \\
\hline Nei & \multirow{2}{*}{$\begin{array}{l}\text { Referanse } \\
-1,77(1,17-2,66)\end{array}$} & \multirow{2}{*}{$\begin{array}{l}\text { Referanse } \\
1,73(1,15-2,63)\end{array}$} \\
\hline Ja & & \\
\hline \multicolumn{3}{|c|}{ Kronisk utmattelse $(n=2310-2328)$} \\
\hline Nei & \multirow{2}{*}{$\begin{array}{l}\text { Referanse } \\
1,49(1,15-1,92)\end{array}$} & \multirow{2}{*}{$\begin{array}{l}\text { Referanse } \\
1,48(1,14-1,91)\end{array}$} \\
\hline Ja & & \\
\hline \multicolumn{3}{|c|}{$\begin{array}{l}\text { Kroniske muskel- og ryggsmerter }(n=2308- \\
2325)\end{array}$} \\
\hline Nei & \multirow{2}{*}{$\begin{array}{l}\text { Referanse } \\
2,17(1,68-2,81)\end{array}$} & \multirow{2}{*}{$\begin{array}{l}\text { Referanse } \\
2,06(1,58-2,67)\end{array}$} \\
\hline Ja & & \\
\hline
\end{tabular}

${ }^{1}$ Separate ujusterte logistiske regresjonsanalyser for hver uavhengige variabel.

${ }^{2}$ Separate logistiske regresjonsanalyser for hver uavhengige variabel justert for kjønn og alder.

\section{Diskusjon}


Andelen pasienter som rapporterte om rastløse bein i studiepopulasjonen, var 14,3\%, og blant disse hadde halvparten moderate eller alvorlige plager. Hver femte pasient rapporterte at plagene var daglige. Kun 13,3\% brukte medikamentell behandling for å lindre plagene. I tillegg fant vi at andelen med rastløse bein var høyere hos pasienter med irritabel tarm, kronisk utmattelse og kronisk muskel- og ryggsmerte enn hos dem uten slike plager.

De fleste studier i den vestlige verden har funnet en forekomst av rastløse bein på 5-10 \% hos voksne $(\underline{1}, 3,4.4)$. Vår studie fra allmennpraksis viser høyere forekomst, noe som kan forklares med at pasienter som oppsøker fastlegen generelt har flere helseproblemer og symptomer enn folk som ikke oppsøker fastlegen, og at det er en assosiasjon mellom rastløse bein og andre lidelser. Vi fant at forekomsten av rastløse bein var signifikant høyere hos pasienter med vanlige plager som irritabel tarm, kronisk utmattelse og kronisk muskel- og ryggsmerte, i tråd med en slik fortolkning. Forekomsten av rastløse bein i vår studie var imidlertid lik den som ble rapportert i en norsk befolkningsundersøkelse fra 2005 (5). Dette motstridende funnet kan forklares av at de diagnostiske kriteriene var litt annerledes i den eldre studien. At vi fant høyere forekomst av rastløse bein blant pasienter med andre vanlige plager, taler for høyere forekomst blant pasienter i allmennpraksis enn i den generelle norske befolkningen.

Mange pasienter med rastløse bein i studien rapporterte moderate eller alvorlige plager, og flertallet sa at de hadde plager to eller flere dager per uke. I alt 20,2 \% beskrev at de hadde plager hver dag. Likevel brukte kun litt over $13 \%$ av pasientene medikamenter av og til $(4,8 \%)$ eller daglig $(8,5 \%)$. Dette kan skyldes at pasienten ikke har tatt opp plagene med fastlegen, at fastlegen ikke har tilbudt medikamentell behandling eller at pasienten ikke $\emptyset$ nsker slik behandling.

At få pasienter får medikamentell behandling, er også vist i andre studier (44,7.). Flere studier viser at kunnskapen om rastløse bein er begrenset blant helsepersonell $(4, \underline{6}, 7.7)$, og det kan være en medvirkende årsak. Anbefalt medikamentell behandling ved rastløse bein er dopaminagonister eller alfa-2-delta-ligander, og effekten er vanligvis god initialt, men kan avta $(3, \underline{11})$. Ved lette plager anbefales ikke-medikamentelle tiltak, men i vår studie fant vi at mange pasienter rapporterte daglige og alvorlige plager, men likevel ikke benyttet medikamenter. Det anbefales at både pasienter og helsepersonell øker oppmerksomheten rundt rastløse bein, siden denne diagnosen er tydelig assosiert med nedsatt livskvalitet (4) og $ø$ kt sykefravær $(\underline{16})$.

Vår studie viser at andelen av pasienter med rastløse bein var klart høyere blant pasienter med andre vanlige plager enn blant pasienter uten slike plager. Det peker på viktigheten av å være ekstra oppmerksom på rastløse bein hos pasienter med slike tilstander.

Assosiasjonen mellom rastløse bein og kronisk utmattelse er ikke overraskende. De fleste pasienter med rastløse bein sover dårlig (4,17.), og dårlig søvn er en kjent årsak til utmattelse og tretthet. Diagnosekriteriene for rastløse bein inneholder ikke krav om smerter. Mange pasienter rapporterer plagene som ubehagelig kribling heller enn som smerter, men likevel rapporterer rundt halvparten av pasienter med rastløse bein at de har smertefulle kriblinger (므). Om det kan forklare noe av assosiasjonen mellom rastløse bein og kronisk muskel- og ryggsmerte, er uklart.

Andre studier viser også sterk assosiasjon mellom rastløse bein og muskel-skjelett-smerter $(\underline{18})$. Assosiasjonen mellom rastløse bein og irritabel tarm er kanskje mer overraskende for klinikere, men en nylig publisert systematisk oversiktsartikkel og metaanalyse viser en tydelig assosiasjon mellom disse (19).). Visceral hypersensitivitet regnes som en viktig patofysiologisk mekanisme ved irritabel tarm, og dopamin er blant flere nevrotransmittere

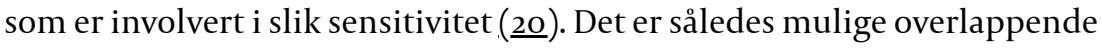
patofysiologiske mekanismer mellom rastløse bein og irritabel tarm. Rastløse bein er assosiert med psykiske lidelser som depresjon (17.). Også irritabel tarm (211), kronisk

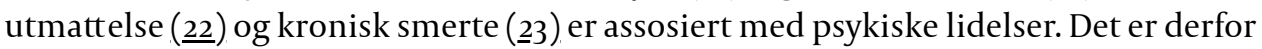


mulig at assosiasjonene mellom rastløse bein og irritabel tarm, kronisk utmattelse og kroniske muskel- og ryggsmerter delvis kan forklares av komorbiditet med psykiske lidelser.

Undersøkelsen vår har både styrker og svakheter. En styrke var det høye antallet pasienter og den høye svarprosenten. Tidligere studier med samme metode har også gitt høy svarprosent $(\underline{12}, 24)$. Dette viser at datainnsamling på fastlegekontoret er en metode som kan gi god representativitet sammenliknet med studier der man samler inn data via telefon eller ved utsending av brev. En sannsynlig forklaring på høy svarprosent er bruk av et kortfattet spørreskjema som er enkelt å fylle ut mens man likevel venter på konsultasjon hos fastlegen. En annen styrke var at pasientene ikke visste på forhånd hva slags spørsmål skjemaet inneholdt. Det reduserer seleksjonsskjevhet. Generaliserbarheten til andre pasienter i allmennpraksis regnes som høy, med det forbehold at materialet vårt har få innvandrere med ikke-vestlig bakgrunn.

En svakhet er at dataene er basert på selvrapportering uten klinisk vurdering av fastlege. Sikker diagnostikk kan naturlig nok ikke baseres på spørreskjemaer alene, men er avhengig av at fastlegen gjør et klinisk intervju og ofte supplerende undersøkelser. Vi vet heller ikke noe om årsaken til legebesøket. Det er en svakhet at vi ikke hadde spørsmål om psykiske lidelser i denne spørreundersøkelsen. Det er mange andre tilstander enn irritabel tarm, kronisk utmattelse og kronisk smerte som ses hyppig på fastlegekontoret. Flere studier på sammenhengen mellom rastløse bein og somatiske og psykiske tilstander anbefales.

\section{KONKLUSJON}

Vi fant forholdsvis høy forekomst av rastløse bein blant pasienter på fastlegekontoret. Mange pasienter med rastløse bein rapporterte mye og hyppige plager, men få benyttet medikamentell behandling. Forekomsten av rastløse bein var signifikant høyere blant pasienter som hadde irritabel tarm, kronisk utmattelse eller kroniske muskel- og ryggsmerter. Blant disse gruppene kan det være hensiktsmessig å være særlig oppmerksom på rastløse bein. Hvorvidt underdiagnostisering - og dermed underbehandling - er et vesentlig problem, bør undersøkes i nye studier.

Vi vil takke medisinstudentene og legepraksisene for utlevering og innsamling av spørreskjemaene. Artikkelen er fagfellevurdert.

\section{LITTERATUR}

1. Garcia-Borreguero D, Cano-Pumarega I. New concepts in the management of restless legs syndrome. BMJ 2017; 356: j104. [PubMed][CrossRef]

2. The international classification of sleep disorders. 3. utg. Darien, IL: American Academy of Sleep Medicine, 2014 .

3. Kinge E, Ulfberg J. Søvnrelaterte bevegelsesforstyrrelser. Tidsskr Nor Legeforen 2009; 129: 1888-91. [PubMed][CrossRef]

4. Allen RP, Walters AS, Montplaisir J et al. Restless legs syndrome prevalence and impact: REST general population study. Arch Intern Med 2005; 165: 1286-92. [PubMed][CrossRef]

5. Bjorvatn B, Leissner L, Ulfberg J et al. Prevalence, severity and risk factors of restless legs syndrome in the general adult population in two Scandinavian countries. Sleep Med 2005; 6:307-12. [PubMed] [CrossRef]

6. Trenkwalder C, Tinelli M, Sakkas GK et al. Socioeconomic impact of restless legs syndrome and inadequate restless legs syndrome management across European settings. Eur J Neurol 2021; 28: 691706. [PubMed][CrossRef] 
7. Memon MD, Faiz S, Zaveri MP et al. Unraveling the mysteries of restless leg syndrome. Cureus 2020; 12: e10951. [PubMed]

8. Hening W, Allen RP, Tenzer P et al. Restless legs syndrome: demographics, presentation, and differential diagnosis. Geriatrics 2007; 62: 26-9. [PubMed]

9. Didato G, Di Giacomo R, Rosa GJ et al. Restless legs syndrome across the lifespan: Symptoms, pathophysiology, management and daily life impact of the different patterns of disease presentation. Int J Environ Res Public Health 2020; 17:3658. [PubMed][CrossRef]

10. Bjorvatn B. T19.6 Restless legs. Norsk legemiddelhåndbok for helsepersonell. https://www.legemiddelhandboka.no/T19.6/Restless_legs Lest 20.9.2021.

11. Liu GJ, Wu L, Lin Wang S et al. Efficacy of pramipexole for the treatment of primary restless leg syndrome: A systematic review and meta-analysis of randomized clinical trials. Clin Ther 2016; 38: 162179.e6. [PubMed][CrossRef]

12. Bjorvatn B, Meland E, Flo E et al. High prevalence of insomnia and hypnotic use in patients visiting their general practitioner. Fam Pract 2017;34: 20-4. [PubMed][CrossRef]

13. Chalder T, Berelowitz G, Pawlikowska T et al. Development of a fatigue scale. J Psychosom Res 1993; 37: 147-53. [PubMed][CrossRef]

14. Wensaas KA, Langeland N, Hanevik K et al. Irritable bowel syndrome and chronic fatigue 3 years after acute giardiasis: historic cohort study. Gut 2012; 61: 214-9. [PubMed][CrossRef]

15. Lacy BE, Mearin F, Chang L et al. Bowel disorders. Gastroenterology 2016; 150: 1393-407. [CrossRef]

16. Durgin T, Witt EA, Fishman J. The humanistic and economic burden of restless legs syndrome. PLoS One 2015; 10: e0140632. [PubMed][CrossRef]

17. Ulfberg J, Bjorvatn B, Leissner L et al. Comorbidity in restless legs syndrome among a sample of Swedish adults. Sleep Med 2007; 8: 768-72. [PubMed][CrossRef]

18. Hoogwout SJ, Paananen MV, Smith AJ et al. Musculoskeletal pain is associated with restless legs syndrome in young adults. BMC Musculoskelet Disord 2015; 16: 294. [PubMed][CrossRef]

19. Guo J, Pei L, Chen L et al. Bidirectional association between irritable bowel syndrome and restless legs syndrome: a systematic review and meta-analysis. Sleep Med 2021; 77: 104-11. [PubMed][CrossRef]

20. Okumura T, Ishioh M, Nozu T. Central regulatory mechanisms of visceral sensation in response to colonic distension with special reference to brain orexin. Neuropeptides 2021; 86: 102129. [PubMed] [CrossRef]

21. Staudacher HM, Mikocka-Walus A, Ford AC. Common mental disorders in irritable bowel syndrome: pathophysiology, management, and considerations for future randomised controlled trials. Lancet Gastroenterol Hepatol 2021; 6: 401-10. [PubMed][CrossRef]

22. Wright A, Fisher PL, Baker N et al. Perfectionism, depression and anxiety in chronic fatigue syndrome: A systematic review. J Psychosom Res 2021;140: 110322. [PubMed][CrossRef]

23. IsHak WW, Wen RY, Naghdechi L et al. Pain and depression: A systematic review. Harv Rev Psychiatry 2018; 26:352-63. [PubMed][CrossRef]

24. Hetlevik $\emptyset$, Garre-Fivelsdal G, Bjorvatn B et al. Patient-reported depression treatment and future treatment preferences: an observational study in general practice. Fam Pract 2019;36: 771-7. [PubMed] [CrossRef]

Publisert: 8. november 2021. Tidsskr Nor Legeforen. DOI: 10.4045/tidsskr.21.0333

Mottatt 22.4.2021, første revisjon innsendt 19.8.2021, godkjent 20.9.2021.

Publisert under åpen tilgang CC BY-ND. Lastet ned fra tidsskriftet.no 26. april 2023. 